\title{
Article \\ Calcium Carbonate Growth with the Ring Structure of Stalactite-Type Minerals in a Tuff Breccia
}

\author{
Ryo Uenishi ${ }^{1}$ and Hitoshi Matsubara ${ }^{2, *}$ D \\ 1 Graduate School of Engineering and Science, University of the Ryukyus, Okinawa 903-0213, Japan; \\ k208479@eve.u-ryukyu.ac.jp \\ 2 Faculty of Engineering, University of the Ryukyus, Okinawa 903-0213, Japan \\ * Correspondence: matsbara@tec.u-ryukyu.ac.jp
}

check for updates

Citation: Uenishi, R.; Matsubara, H. Calcium Carbonate Growth with the Ring Structure of Stalactite-Type Minerals in a Tuff Breccia. Crystals 2021, 11, 1117. https://doi.org/ $10.3390 /$ cryst11091117

Academic Editors: Hamed Khodadadi Tirkolaei,

Satoru Kawasaki, Liang Cheng and Leon van Paassen

Received: 17 August 2021

Accepted: 11 September 2021

Published: 14 September 2021

Publisher's Note: MDPI stays neutra with regard to jurisdictional claims in published maps and institutional affiliations.

Copyright: (c) 2021 by the authors. Licensee MDPI, Basel, Switzerland. This article is an open access article distributed under the terms and conditions of the Creative Commons Attribution (CC BY) license (https:// creativecommons.org/licenses/by/ $4.0 /)$.

\begin{abstract}
Microbially induced carbonate precipitation (MICP) has attracted worldwide attention as an environmentally friendly ground restoration technology in response to geohazards. This study describes the relationship between calcium carbonate growth within stalactite-type minerals formed around fractures in tuff breccia and microorganisms. Scanning electron microscopy revealed that calcium carbonate was precipitated in the interstices of rings formed in stalactite-type minerals, as if the carbonate minerals enhanced the strength of the silicate minerals. In addition, X-ray powder diffraction analysis detected that the calcium carbonates were calcite and vaterite. Moreover, microorganisms, such as diatoms and green algae, inhabited the interstices and, consequently, MICP by these microorganisms could play a role in the stability of outcrops. The stable isotope ratios of $\delta^{13} \mathrm{C}$ and $\delta^{15} \mathrm{~N}$ and the mass spectral signals of the demineralized samples also encouraged diatoms and green algae to be involved in the formation of minerals.
\end{abstract}

Keywords: calcium carbonate; stalactite-type minerals; ring structure; diatom; green algae; microbially induced carbonate precipitation

\section{Introduction}

The metabolic reactions of microorganisms inhabiting the surface and inner layers of various rocks significantly affect the properties and characteristics of the rocks [1]. Metabolic reactions have had a significant impact on the mineralization and weathering of rocks over the last 4 billion years [1,2]. Recent studies based on field investigations and laboratory experiments have improved our understanding of the impacts of microbial metabolism on the earth's surface and subsurface in the fields of geology and geological engineering [3-5], although the influence of landscape dynamics has been neglected in the field of geomorphology [6]. As a result, it has been suggested that biomineralization could significantly impact the strength of rock materials; therefore, the development of beneficial applications of microorganism and mineral interactions is critical in the field of geotechnical engineering.

For example, studies have focused on developing ecological techniques for repairing limestone using biomineralization [7-9]. Calcium carbonate can be used as a repairing material by biomediated precipitation as a by-product of microbial metabolic reactions such as photosynthesis [3,9-12] and urea decomposition [3,9,13-24]. In these biomediated environments, the cell wall and extracellular polymeric substances of the microorganism act as centers for carbonate precipitation $[1,3,25]$. This means that having activated microorganisms in the cracks and discontinuities of cracks facilitates the precipitation of biomediated calcium carbonate, which also acts as an adhesive material and increases rock strength and stability $[9,11,12,26]$.

Biomediated calcium carbonate is used as a filler in pores and cracks, and biomediated precipitation is called microbially induced carbonate precipitation (MICP) [3,9]. 
Although significant efforts have been devoted to developing such microbiological repairing technologies for discontinuous rocks, their application to actual environments is yet to be investigated. Most of the work has been performed on the application of MICP to soil improvement techniques, and thus, MICP is expected to be the next-generation soil improvement technology $[9,13]$. In these applications, the strength and stability of sandy soil were increased by the precipitation of biomediated calcium carbonate used as the adherent material.

In this study, we investigated a stalactite-type mineral within silicate and carbonate minerals on the surface of tuff breccia in the coastal area of Aguni Island in Okinawa, Japan. In the minerals, various microorganisms such as diatoms and green algae have inhabited. This study describes the relationship between calcium carbonate growth within stalactitetype minerals and microorganisms from mechanical, chemical, and biological perspectives.

\section{Materials and Methods}

\subsection{Materials}

Aguni Island is a small island in Okinawa, Japan. From a geological viewpoint, there is a fault called the Aguni Fault that cuts the Ryukyu Group on Aguni Island [27], where the Ryukyu group is mainly composed of coral limestones called Ryukyu limestone, which is distributed over a wide area of the island. In contrast, tuff breccia and fine tuff called Aguni tuffs are distributed in the southwestern part of the island, where the rock thickness reaches $30 \mathrm{~m}$. The Aguni tuffs consist of andesitic lava, homogeneous tuff breccia, and volcanic breccia [27].

In Aguni Island, we found stalactite-type minerals (hereinafter, called 'stalactite minerals') forming on the outcrops and cave wall of the tuff breccia along the coastal area described in Figure 1. The cave shown in Figure 1A is composed of alternating layers of lava and lapilli tuff or tuff breccia and is considered to be a lava cave caused by lava fissures and weathering. Although seawater may enter the cave at high tide and the lower part may be submerged in seawater, this occurrence is limited to spring tides and typhoons. However, a large amount of spring water drips from the cracks in the cave wall. The stalactite minerals were formed on the surfaces of the outcrops and along the cracks, as shown in Figure 1. Interestingly, most of the stalactite minerals were observed to be growing in a direction perpendicular to the rock surface. In the current study, stalactite minerals were sampled from tuff breccia outcrops and the cave wall for analysis.
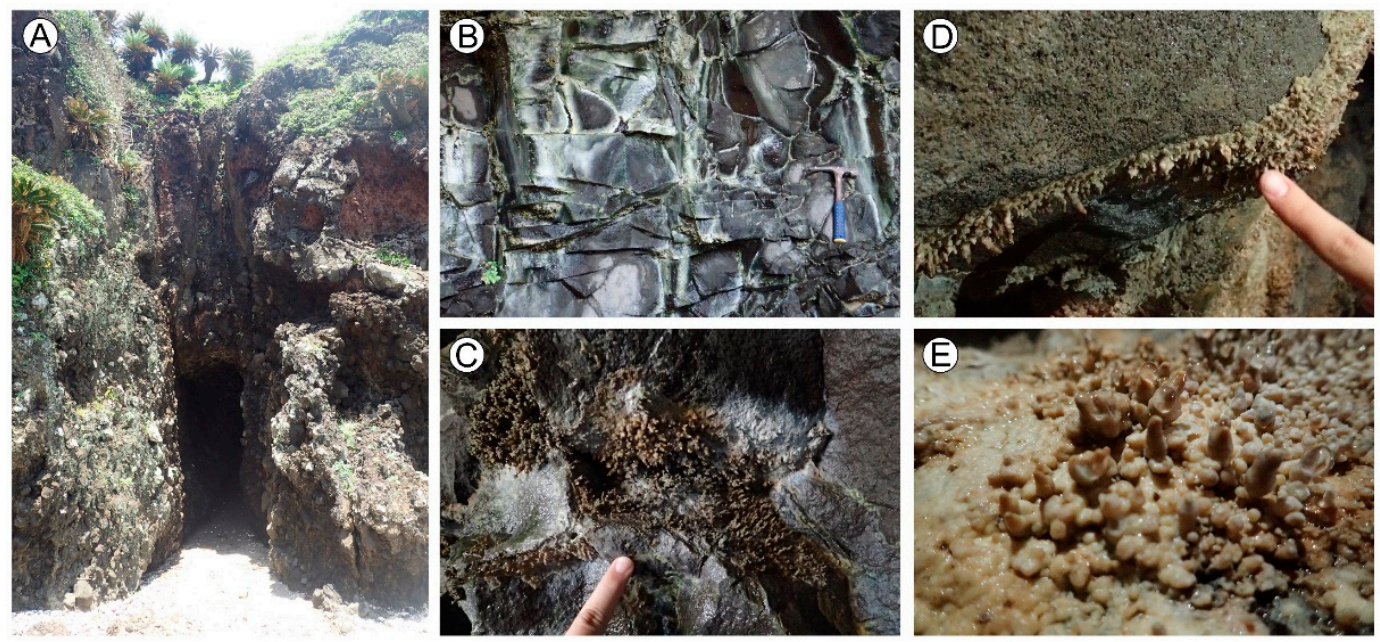

Figure 1. Outcrop of the tuff breccia in Aguni Island. (A) cave appearance; (B) cracking condition of the outcrop; $(\mathbf{C})$ stalactite minerals along cracks; $(\mathbf{D}, \mathbf{E})$ stalactite minerals covering the surface of the host rock. 


\subsection{Strength and Morphology of Stalactite Minerals, and Properties of Spring Water}

A Schmidt hammer [28] was used in situ to evaluate the strength of the stalactite minerals. Here, the differences in the estimated uniaxial compressive strength (UCS) from the repulsion value obtained using the Schmidt hammer tests between the host rock and the stalactite minerals covered rock (hereinafter, called as 'sm-covered rock') were investigated by averaging the impulsion values from nine points of each outcrop and comparing the averaged values. Although UCS evaluation by the Schmidt hammer test must be carried out carefully when conducting hardness measurements in the field, the estimated values provide an opportunity to identify and compare the physical state of the rock surface [29]. Therefore, a relative valuation between the host rock and cover rock should be possible. The estimated UCS can be obtained using the equation $F_{c}=18.0-1.27 R$, where $F_{c}$ is the estimated UCS, and $R$ is the repulsion value obtained by the Schmidt hammer test. Additionally, approximately 100 stalactite minerals were randomly sampled from the cave wall and outcrop, and their diameters and lengths were measured.

The chemical properties of the spring water dripping from the cave wall were analyzed using inductively coupled plasma mass spectrometry (ICP-MS; ICPE-9000, Shimadzu, Kyoto, Japan) [30] to analyze the chemical origin of the stalactite minerals. The samples were collected from around the entrance and the innermost part of the cave.

\section{3. $p H$ Values and Microstructures}

Three samples of stalactite minerals and host rocks were directly collected and the $\mathrm{pH}$ values of each sample were measured. First, $10 \mathrm{~g}$ of finely crushed samples were added to $100 \mathrm{~mL}$ of deionized water and the $\mathrm{pH}$ was adjusted to 7.0 using sodium hydroxide. After $10 \mathrm{~min}$, the $\mathrm{pH}$ was measured using a $\mathrm{pH}$ meter. The inner and lateral structures of the collected samples were observed using a scanning electron microscope (SEM; TM3030, Hitachi High Tech, Tokyo, Japan), and element maps were created using an energy dispersive X-ray analyzer system (EDS; TM3030, Hitachi High Tech, Tokyo, Japan).

\subsection{Mineral Classification}

The mineral composition of the stalactite minerals was identified using $\mathrm{X}$-ray powder diffraction (XRD; RINT ULTIMA/PC, Rigaku, Tokyo, Japan). The measurement conditions were set as follows: scan speed, $4^{\circ}$; voltage, $40 \mathrm{kV}$; current, $30 \mathrm{~mA}$; sampling width, $0.02^{\circ}$; divergence slit, $1^{\circ}$; scattering slit, $1^{\circ}$; and light-receiving slit, $0.3 \mathrm{~mm}$. The relative mineral abundances of the detected minerals were calculated using the weight ratio.

\subsection{Carbon and Nitrogen Stable Isotope Ratios}

The natural abundance ratio of stable isotopes is often used as a parameter for material circulation [31]. In general, the carbon isotope ratio is used as an indicator of the inflow of terrestrial organic matter and the organic matter production of planktonic and attached microalgae, and the nitrogen isotope ratio is used as an indicator of the eutrophic stage of anthropogenic origin [32]. The analysis using both the stable carbon isotope ratio $\left(\delta^{13} \mathrm{C}\right)$ and stable nitrogen isotope ratio $\left(\delta^{15} \mathrm{~N}\right)$ may indicate the photosynthetic pathway, living environment, and nutritional origin $[33,34]$; thus, these ratios can be used to estimate the biological environment for the evolution of stalactite minerals. For this purpose, a $\delta^{13} \mathrm{C}-\delta^{15} \mathrm{~N}$ map of stalactite minerals was provided in this study.

\subsection{Mass Spectrometry}

Stalactite minerals were analyzed by electrospray ionization mass spectrometry (ESI-MS; LC-20AD XR, Shimadzu, Kyoto, Japan) to identify the chemical substances in the stalactite minerals and identify a biosignature. The analysis was conducted based on the experiment of Götze et al. (2020). The calcium carbonate in the stalactite minerals was demineralized in $6 \mathrm{M}$ hydrochloric acid $(\mathrm{HCl})$ for $24 \mathrm{~h}$ at $90{ }^{\circ} \mathrm{C}$, and the resulting solution was filtered through a $0.2 \mu \mathrm{m}$ filter and freeze-dried to remove excess $\mathrm{HCl}$ [35]. 
The remaining solid was dissolved in water for the ESI-MS analysis. The obtained spectrum was identified by MassBank, a high-quality mass spectral database for life sciences [36].

\section{Results}

\subsection{Strength and Morphology of Stalactite Minerals, and Properties of Spring Water}

The estimated uniaxial compressive strengths from an in situ Schmidt hammer test on the surface of the host rock and the sm-covered rock were $21.36 \pm 6.21 \mathrm{MPa}$ and $13.67 \pm 7.12 \mathrm{MPa}$, respectively. Figure 2 shows the histograms of the diameter and length of the stalactite minerals, as morphological parameters of their characteristics. Most stalactite minerals have a diameter ranging from 1.1 to $6.8 \mathrm{~mm}(2.46 \pm 0.88 \mathrm{~mm}$; Figure $2 \mathrm{~A})$, and a length ranging from 2.4 to $23.3 \mathrm{~mm}(9.05 \pm 4.45 \mathrm{~mm}$; Figure 2B).

(A)

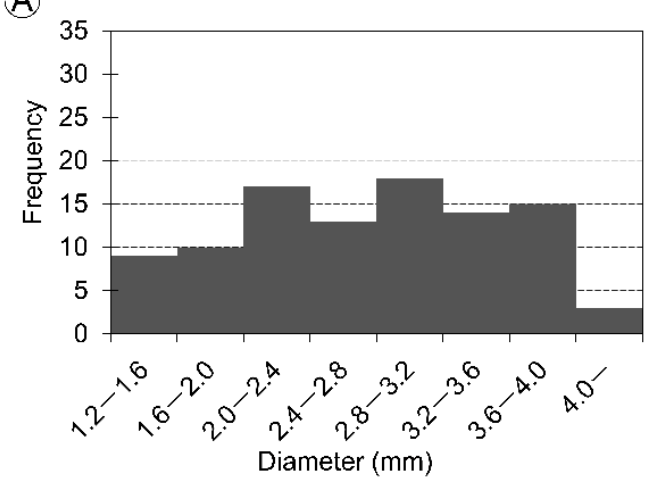

(B)

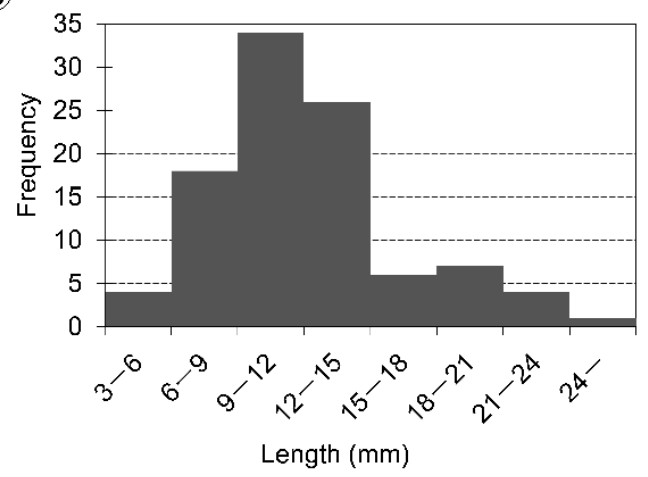

Figure 2. Histograms of the diameter and length of the stalactite minerals (number of samples: 100). (A): diameter; (B): length.

Figure 3 shows the elemental distribution of the spring water collected from the cave wall around the entrance and the innermost part of the cave. In both cases, approximately the same number of elements was detected. The elemental distribution also indicates that the spring water is a freshwater source that penetrates the ground surface because its constituent elements are different from those of seawater. Furthermore, it is noted that the contents of $\mathrm{Mg}, \mathrm{Ca}$, and $\mathrm{Si}$ were high in the spring water samples.

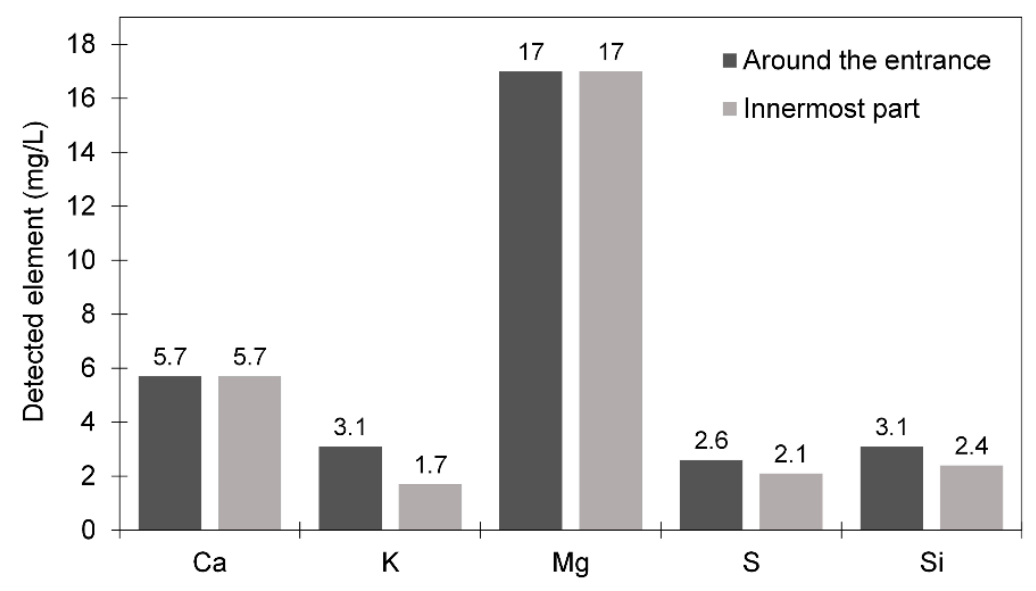

Figure 3. Element distribution in the spring water from the cave wall.

\section{2. $\mathrm{pH}$ Values and Microstructures}

Figure 4 shows the $\mathrm{pH}$ results of the host rock, stalactite minerals from the cave wall, and stalactite minerals from the outcrop. Although, all the samples indicate weak alkaline properties $(\mathrm{pH}=8.11-8.78)$, the $\mathrm{pH}$ values of the stalactite minerals are higher than those of the host rock, especially on the outcrop. Evidently, increases in $\mathrm{pH}$ on the cave wall and outcrop are profoundly linked to the existence of stalactite minerals. However, it is 
known that microorganisms increase the $\mathrm{pH}$ and promote the deposition of carbon dioxide in the form of calcium carbonate [7]. Hence, these increases can be associated with the metabolism of microorganisms inhabiting stalactite minerals.

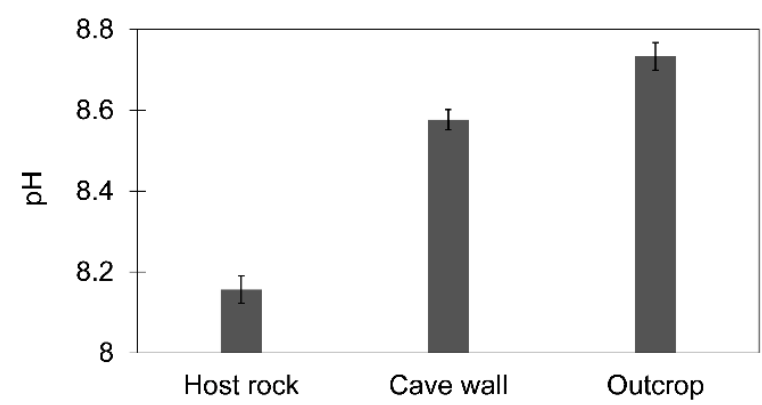

Figure 4. $\mathrm{pH}$ values of host rock and stalactite minerals from the cave wall and outcrop.

Figure 5 shows SEM images of the interior of the stalactite minerals. Figure $5 \mathrm{~A}$ shows that the stalactite minerals have a ring structure. In the interstices of the ring structure, calcium carbonate precipitated and appeared to enhance the strength of the silicate minerals (Figure 5B). In addition, the fillers in the interstices contained spherical and flower-like minerals (Figure 5C,D) and microorganisms (Figure 5E,F) such as diatoms and green algae.
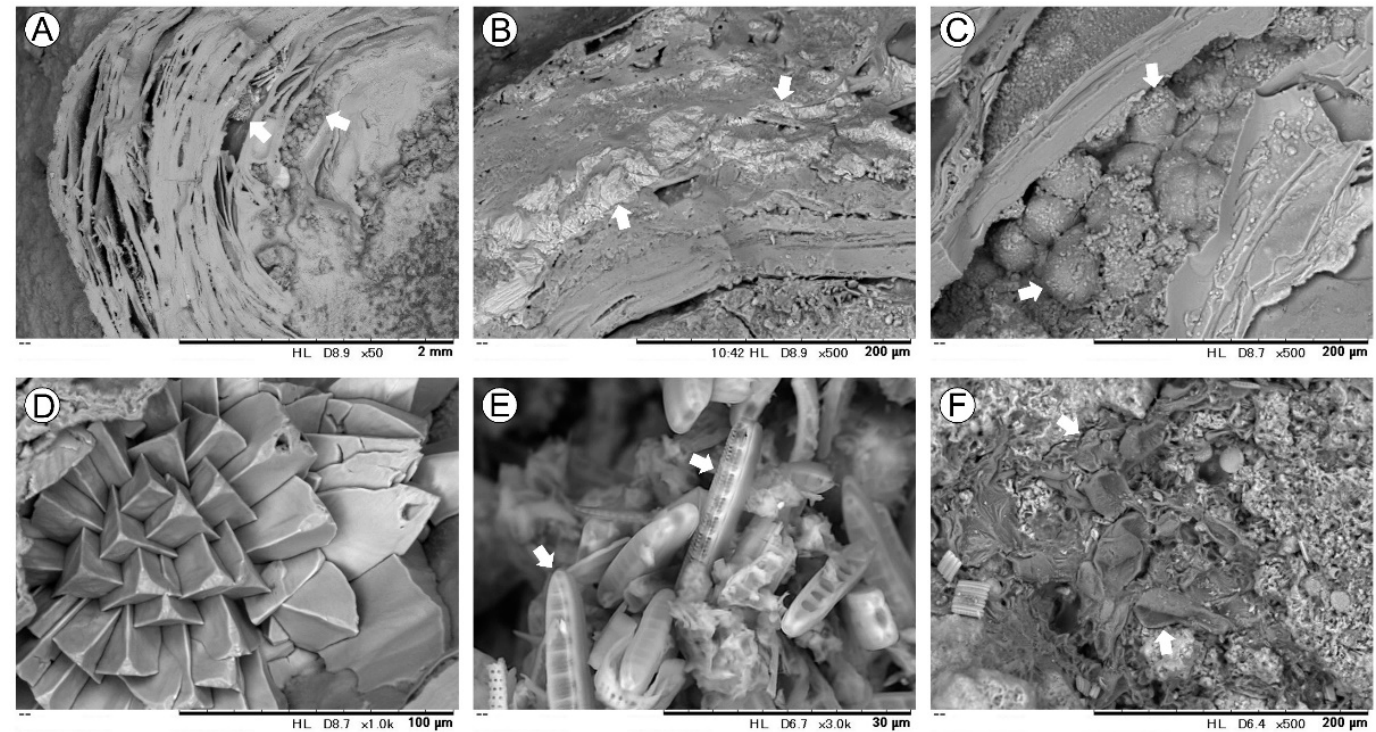

Figure 5. SEM images of the stalactite minerals. (A) cross-section (white arrows: carbonate minerals); (B-D) carbonate minerals between the rings of the silicate mineral; $(\mathbf{E})$ diatoms; $(\mathbf{F})$ green algae.

Figure 6 shows the elemental mapping of the cross-section of the stalactite minerals. It is observed from this figure that the fillers are tightly packed in different parts of the interstices. The rim structure is composed of silica, magnesium, and oxygen, while the fillers, including spherical structures, are composed of calcium, carbon, and oxygen. 
(A)
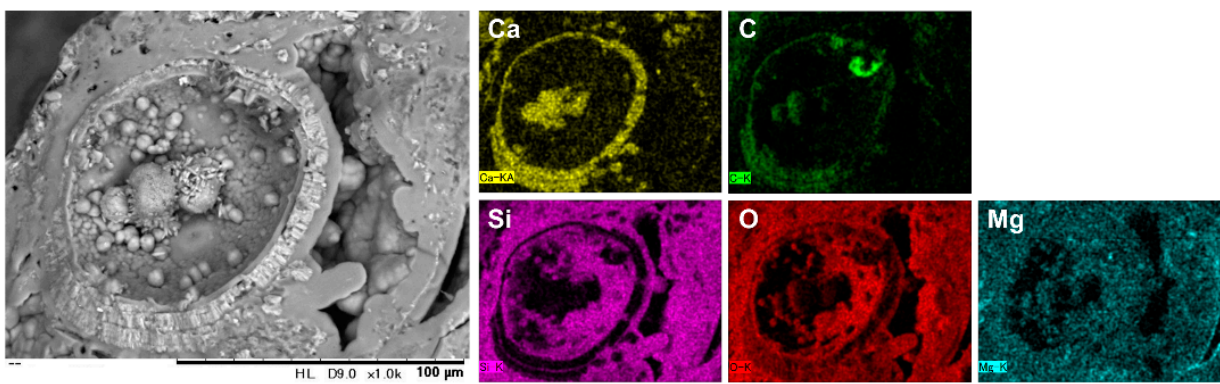

(B)
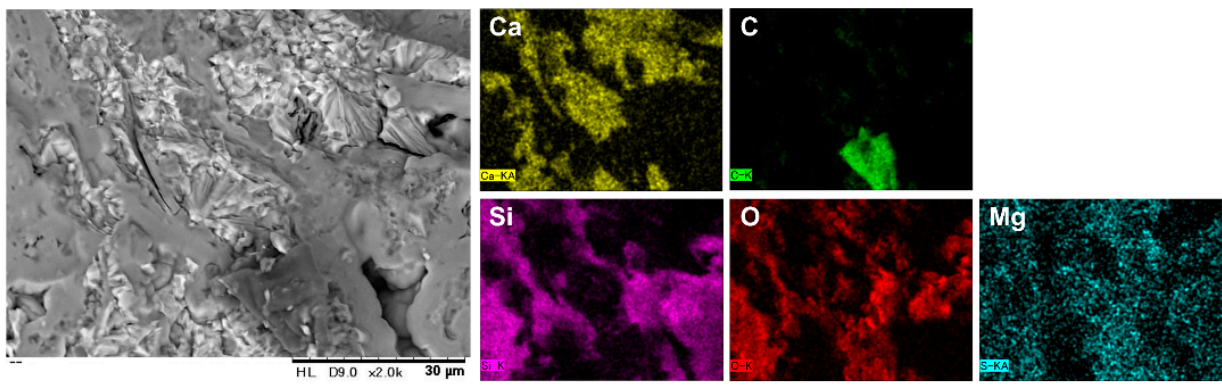

Figure 6. Element mappings of the cross-section of stalactite minerals. (A) calcium carbonate developing between ring structures; (B) banded carbonate structure. Ca: calcium, C: carbon, Si: silica, $\mathrm{O}$ : oxygen, and Mg: magnesium.

\subsection{Mineral Classification}

Figure 7A shows the intensity distribution of the stalactite minerals measured using XRD: Calcite $\left(\mathrm{CaCO}_{3}\right)$, vaterite $\left(\mathrm{CaCO}_{3}\right)$, quartz $\left(\mathrm{SiO}_{2}\right)$, and epsomite $\left(\mathrm{MgSO}_{4}\right)$ were detected. Figure 7B shows the relative abundance of the minerals detected in the stalactite minerals. It is understood from this figure that the stalactite minerals are composed of $89 \%$ quartz, $7.5 \%$ calcium carbonates (5.6\% calcite and $1.9 \%$ vaterite), and $3.1 \%$ epsomite.

(A)

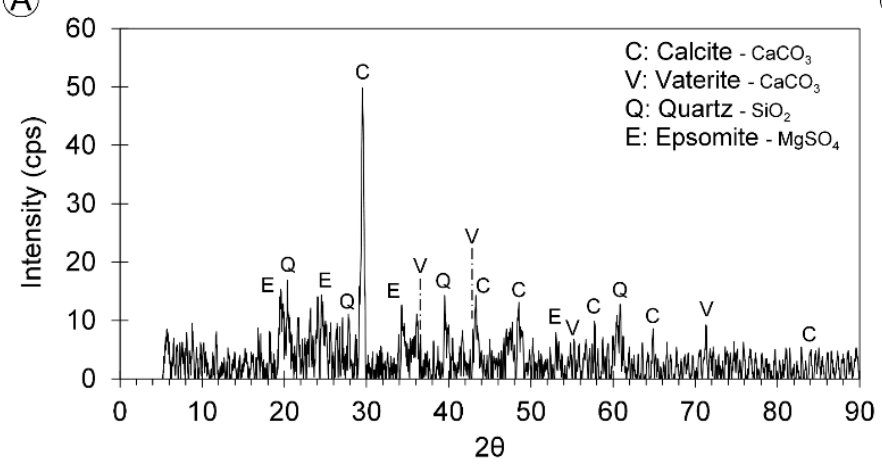

(B)

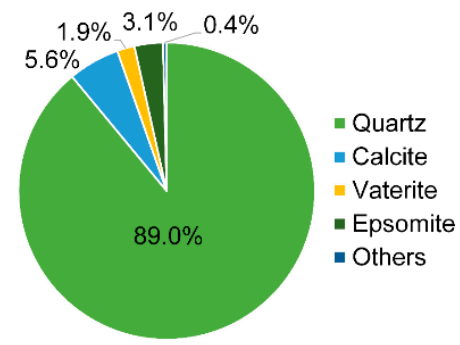

Figure 7. Intensity distribution of the stalactite minerals by the powder X-ray diffraction analysis. (A) diffraction pattern; (B) relative mineral abundance of the detected minerals.

\subsection{Carbon and Nitrogen Stable Isotope Ratios}

Figure 8 shows the relationship between the carbon and nitrogen stable isotope ratios where the samples were collected from six points on the cave wall and the outcrop. The carbon and nitrogen stable isotope ratios range from -18.6 to $-7.3 \%$ and -1.3 to $4.2 \%$, respectively. Although the $\delta^{13} \mathrm{C}$ and $\delta^{15} \mathrm{~N}$ values were dispersed, they were distributed in nearly the same range, independent of the sampling points. 


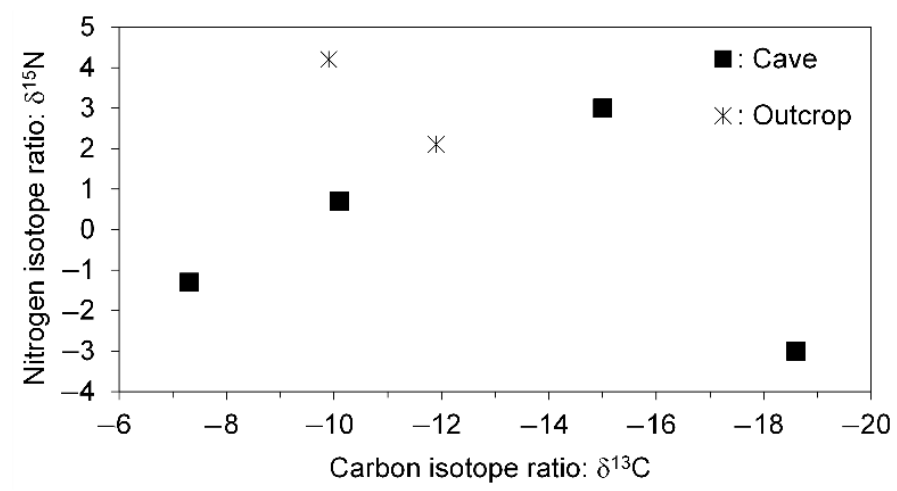

Figure 8. Carbon and nitrogen stable isotope ratios of the stalactite minerals.

\subsection{Mass Spectrometry}

ESI-MS analysis is useful for identifying chemicals in the stalactite minerals and finding a biosignature. Figure 9 shows the spectra of the demineralized sample and phenylalanine, which is an essential amino acid and also a strong biosignature, where the spectral intensity was normalized by the maximum intensity of each sample. In the stalactite minerals, there were several spectral signals between $m / z=100$ and $m / z=300$ (Figure 9A). In contrast, phenylalanine has two main signals with $m / z=120.08$ and $m / z=166.09$. Evidently, the spectral signals of the demineralized sample include those of phenylalanine.

\section{(A)}

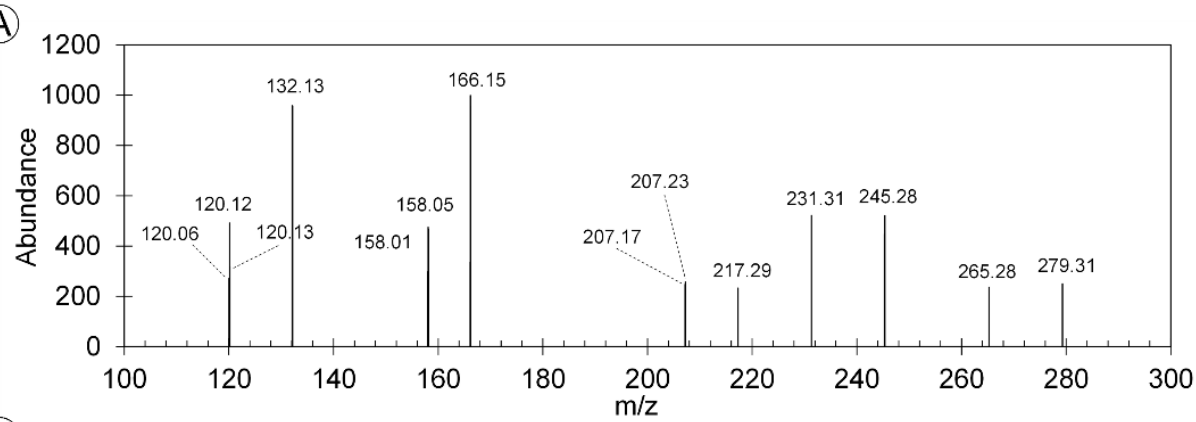

(B)

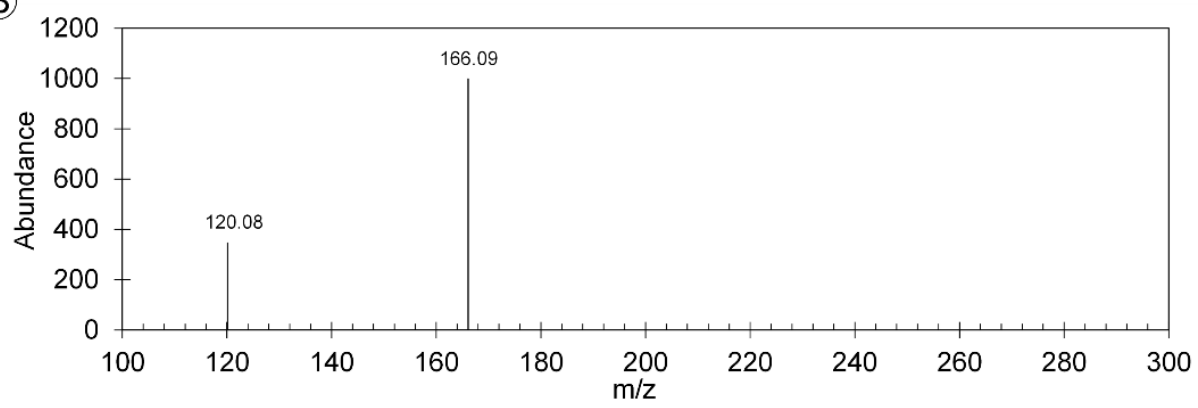

Figure 9. Spectra of ESI-MS. (A) demineralized stalactite minerals by $6 \mathrm{M} \mathrm{HCl}$; (B) phenylalanine $[36,37]$ by MassBank.

\section{Discussion}

The main component of the stalactite minerals is quartz $\left(\mathrm{SiO}_{2} ;\right.$ Figure 7$)$, and the rim structures of the minerals are composed of quartz and epsomite (Figures 6 and 7). Interestingly, there are various microorganisms, such as diatoms and green algae in the interstices of stalactite minerals (Figure 5E,F), and these microorganisms could play a role in the formation of silicate minerals.

The physicochemical formation process of silicate minerals is divided into three steps: weathering effect, hydrothermal action, and chemical and microbial diagenesis [38]. Microorganisms have also been found to play a role in the formation of silicate miner- 
als $[1,39,40]$. The formation process does not necessarily follow a single pathway because it is a complex process, which is influenced by microbiological, chemical, mechanical, geographical, and climatic factors [41]. In particular, the origin of the stalactite minerals could be influenced by phototrophic-microbiological factors since diatoms and green algae were observed (Figure 5E,F), therefore, the stalactite minerals grew in the direction of the light source with a ring structure (Figure 1C-E), which indicates the involvement of photoautotrophic microorganisms. Additionally, the diameter of the stalactite minerals is widely distributed (Figure 2), they can be considered to be growing at the time of measurement. The fact that the $\mathrm{pH}$ of the stalactite minerals is higher than that of the host rock (Figure 4) indicates that the minerals may be of biological origin [7], and the microorganisms could be diatoms and green algae based on the SEM observations (Figure 6). Naturally, the silicate minerals may have originated from diatom carcasses, given the abundance of these forms within and on the sample's surface.

The environment suitable for primary producers such as diatoms and green algae has $\delta^{13} \mathrm{C}$ and $\delta^{15} \mathrm{~N}$ values ranging from -17.3 to $-7.5 \%$ and 0 to $4 \%$, respectively [42-44]. The stable isotopes of the stalactite minerals were also distributed close to this range, as shown in Figure 8. Moreover, it is known that the optimum $\mathrm{pH}$ value for the growth of photosynthetic microorganisms such as diatoms and green algae is approximately $7-8[45,46]$, and the stalactite minerals in this study are also weakly alkaline, as shown in Figure 4. Hence, the metabolic reactions of diatoms and green algae are related to the formation of stalactite minerals.

In terms of microbial mineralization, a silicate rock called a diatom stalactite with similar characteristics as the stalactite minerals is observed along the direction of the light and perpendicular to the spring water flow in caves with relatively high humidity worldwide [47-50]. Aguni Island also has a relatively high average temperature and precipitation level. There is a large amount of spring water in the cave, which keeps the humidity level very high throughout the year and this makes the cave an ideal environment for the development of diatom stalactites. It is also known that most diatoms, such as diadesmis gallica, laevissima, and orthoseira roeseana, grow best in the $\mathrm{pH}$ range of 5.6-8.5 [51]. The $\mathrm{pH}$ values of the stalactite minerals were also distributed within this range (Figure 4).

Interestingly, some interstices are filled with calcium carbonate. From Figures 6 and 7, the calcium carbonate composed of calcite, vaterite, and amorphous calcium carbonate (ACC) with a spherical structure, as shown in Figure 5C, can also be generated. It is likely that the flower-like calcium carbonate, as shown in Figure 5D, is vaterite because of its structural features. In general, calcium carbonate minerals are extremely sensitive to dissolution and precipitation [52]. ACC can be generated by the reaction between calcium hydroxide and carbon dioxide at room temperature and then gradually transformed into vaterite and calcite [53]. These calcium carbonates play a role in bonding the rings and increasing the strength of stalactite minerals; microorganisms such as diatoms and green algae have a strong impact on this precipitation. Naturally, diatoms and green algae convert light energy into chemical energy via photosynthesis. Hence, the calcium carbonate in the interstices is precipitated as a by-product of photosynthesis [3,9-12]. The ESI-MS signals of the demineralized samples included those of phenylalanine, an essential amino acid, and the existence of phenylamine becomes a strong biosignature (Figure 9). Hence, it is considered that these microorganisms induce the precipitation of the calcium carbonate minerals.

The silica, calcium, and magnesium elements in the stalactite minerals and host rock are considered to have been dissolved in spring water from fractures because the composition of the stalactite minerals and spring water are almost identical (Figures 3, 6, and 7). Hence, the following reactions occur within stalactite minerals $[1,11]$ :

$$
\mathrm{HCO}_{3}^{-}+\mathrm{H}_{2} \mathrm{O} \rightarrow \mathrm{CH}_{2} \mathrm{O}+\mathrm{O}_{2}+\mathrm{OH}^{-}
$$


where $\mathrm{HCO}_{3}^{-}, \mathrm{H}_{2} \mathrm{O}, \mathrm{CH}_{2} \mathrm{O}, \mathrm{O}_{2}$ and $\mathrm{OH}^{-}$are barbonate, water, formaldehyde, oxygen, and hydroxide, respectively. Photoautotrophic microorganisms release hydroxide ions to generate carbonate ions:

$$
\mathrm{HCO}_{3}^{-}+\mathrm{OH}^{-} \leftrightarrow \mathrm{CO}_{3}^{2-}+\mathrm{H}_{2} \mathrm{O}
$$

where $\mathrm{CO}_{3}^{2-}$ is carbonate. Eventually, the carbonate ions and calcium ions in the spring water bond and precipitate calcium carbonate:

$$
\mathrm{CO}_{3}^{2-}+\mathrm{Ca}^{2+} \leftrightarrow \mathrm{CaCO}_{3} \downarrow
$$

where $\mathrm{Ca}^{2+}$. and $\mathrm{CaCO}_{3}$ are calcium and calcium carbonate, respectively. The growth mechanisms of the stalactite minerals are shown in Figure 10.

(A)

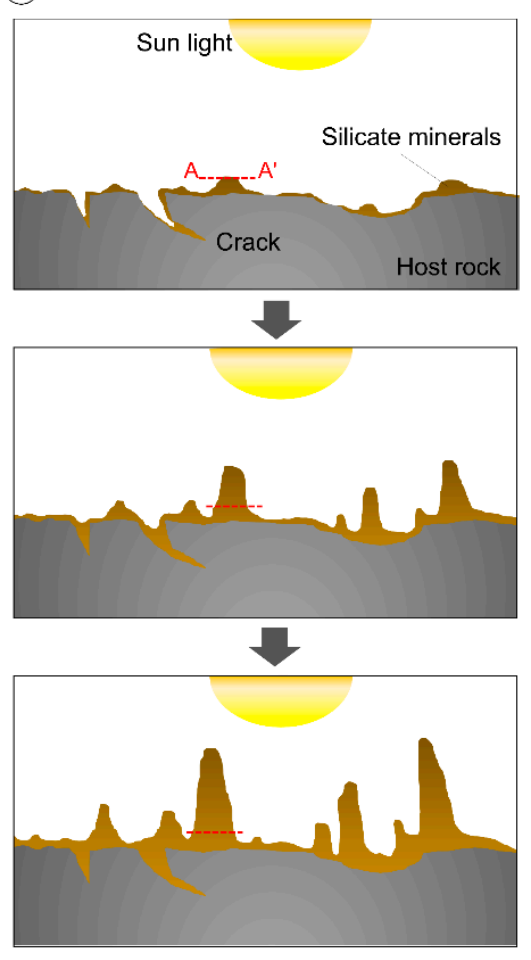

(B)

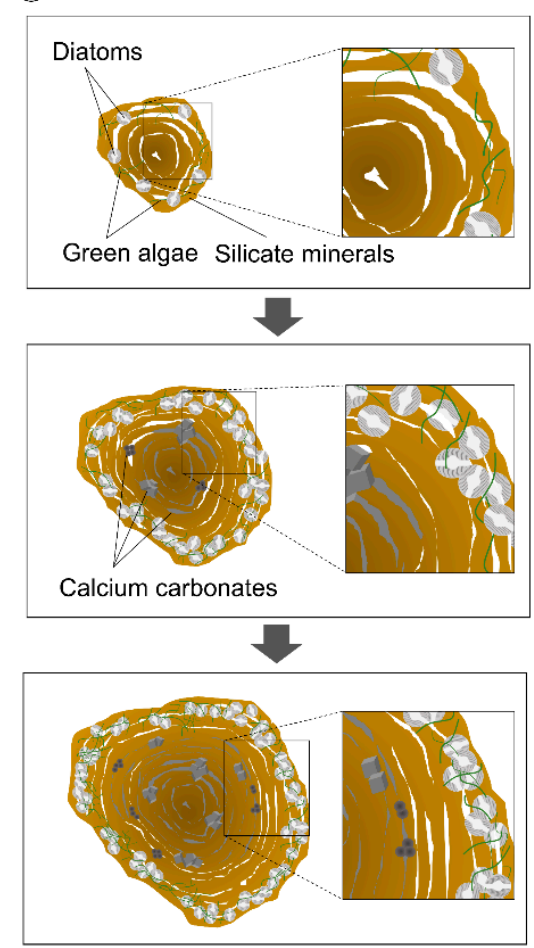

Figure 10. Formation mechanism (temporal growing) of stalactite minerals. (A) state from a side face; (B) state of the cross-section.

In terms of mechanical properties, the compressive strength of the sm-covered rock was lower than that of the host rock and its standard deviation was larger. This result suggests that stalactite minerals grow randomly to cover the rock surfaces and fractures. Their strength is expected to increase steadily because the interstices between the rings are gradually filled with calcium carbonate, calcite, vaterite, and ACC. Therefore, additional engineering techniques, such as artificial forming techniques for stalactite minerals should be developed in response to future geohazards.

\section{Conclusions}

The formation mechanism of stalactite minerals in Aguni Island, Japan was investigated from mechanical, chemical, and biological perspectives. The results can be summarized as follows:

(1) Stalactite minerals are potential diatom stalactites and have ring structures where biomediated calcium carbonate exists in the interstices. The existence of microorganisms and their metabolism significantly contribute to the formation of stalactite minerals. 
(2) The interstices between the rings are filled with calcium carbonates; thus, the strength of the stalactite minerals is expected to increase steadily. Diatoms and green algae should also facilitate the generation of calcium carbonate.

(3) Stalactite minerals are mainly composed of quartz, calcite, vaterite, and epsomite; however, silica, calcium, and magnesium are obtained from spring water.

(4) Since the mass spectral signals of the demineralized samples include phenylalanine, the origin of the calcium carbonate minerals in the stalactite minerals is microbiological.

A detailed investigation of the origin of the silicate materials, including the literature reviews of diatoms, has not been conducted in this study because this study focuses on calcium carbonates in the ring structure of the stalactite minerals; this will be reported in another study after silicate material analysis is carried out. Although the species of microorganisms in stalactite minerals have not been identified in this study, the results suggest the applicability of a self-organizing rock repair technology based on stalactite minerals. In the future, additional engineering techniques should be developed in response to geohazards.

Author Contributions: Conceptualization, H.M.; Data curation, R.U. and H.M.; Formal analysis, R.U. and H.M.; Funding acquisition, H.M.; Investigation, R.U. and H.M.; Methodology, H.M.; Supervision, H.M.; Validation, R.U. and H.M.; Writing—original draft, R.U.; Writing—review \& editing, H.M. All authors have read and agreed to the published version of the manuscript.

Funding: This work has been partly supported by JSPS KAKENHI, grant number 21K18754.

Data Availability Statement: All data generated or analyzed during this study are included in this article.

Acknowledgments: The authors acknowledge the helpful comments and discussions by Naoya Shinzato, Kosaburo Hirose, and Shinichi Gima of University of the Ryukyus.

Conflicts of Interest: The authors declare no conflict of interest.

\section{References}

1. Konhauser, K. Introduction to Geomicrobiology; Blackwell Publishing: Oxford, UK, 2007.

2. Büdel, B.; Weber, B.; Kühl, M.; Pfanz, H.; Sültemeyer, D.; Wessels, D. Reshaping of sandstone surfaces by cryptoendolithic cyanobacteria: Bioalkalization causes chemical weathering in arid landscapes. Geobiology 2004, 2, 261-268. [CrossRef]

3. Zhu, T.; Dittrich, M. Carbonate precipitation through microbial activities in natural environment, and their potential in biotechnology: A review. Front. Bioeng. Biotechnol. 2016, 4, 4. [CrossRef]

4. Miller, H.R.; Lane, S.N. Biogeomorphic feedbacks and the ecosystem engineering of recently deglaciated terrain. Prog. Phys. Geogr. Earth Environ. 2019, 43, 24-45. [CrossRef]

5. Wieler, N.; Ginat, H.; Gillor, O.; Angel, R. The origin and role of biological rock crusts in rocky desert weathering. Biogeosciences 2019, 16, 1133-1145. [CrossRef]

6. Viles, H.A. Microbial geomorphology: A neglected link between life and landscape. Geomorphology 2012, 157, 6-16. [CrossRef]

7. Dick, J.; De Windt, W.; De Graef, B.; Saveyn, H.; Van der Meeren, P.; De Belie, N.; Verstraete, W. Bio-deposition of a calcium carbonate layer on degraded limestone by Bacillus species. Biodegradation 2006, 17, 357-367. [CrossRef] [PubMed]

8. Micallef, R.; Vella, D.; Sinagra, E.; Zammit, G. Biocalcifying Bacillus subtilis cells effectively consolidate deteriorated Globigerina limestone. J. Ind. Microbiol. Biotechnol. 2016, 43, 941-952. [CrossRef]

9. Rahman, M.M.; Hora, R.N.; Ahenkorah, I.; Beecham, S.; Karim, M.R.; Iqbal, A. State-of-the-art review of microbial-induced calcite precipitation and its sustainability in engineering applications. Sustainability 2020, 12, 6281. [CrossRef]

10. Dupraz, C.; Visscher, P.T.; Baumgartner, L.K.; Reid, R.P. Microbe-mineral interactions: Early carbonate precipitation in a hypersaline lake (Eleuthera Island, Bahamas). Sedimentology 2004, 51, 745-765. [CrossRef]

11. Oshiro, H.; Matsubara, H. Carbonate precipitation through photoautotrophic microorganisms at the Giza cliff in Okinawa, Japan. Environ. Earth Sci. 2018, 77, 591. [CrossRef]

12. Matsubara, H. Stabilisation of weathered limestone surfaces using microbially enhanced calcium carbonate deposition. Eng. Geol. 2021, 284, 106044. [CrossRef]

13. DeJong, J.T.; Mortensen, B.M.; Martinez, B.C.; Nelson, D.C. Bio-mediated soil improvement. Ecol. Eng. 2010, 36, 197-210. [CrossRef]

14. Ross, N.; Villemur, R.; Deschênes, L.; Samson, R. Clogging of a limestone fracture by stimulating groundwater microbes. Water Res. 2001, 35, 2029-2037. [CrossRef] 
15. Cuthbert, M.O.; McMillan, L.A.; Handley-Sidhu, S.; Riley, M.S.; Tobler, D.J.; Phoenix, V.R. A field and modeling study of fractured rock permeability reduction using microbially induced calcite precipitation. Environ. Sci. Technol. 2013, 47, 13637-13643. [CrossRef]

16. Minto, J.M.; MacLachlan, E.; El Mountassir, G.; Lunn, R.J. Rock fracture grouting with microbially induced carbonate precipitation. Water Resour. Res. 2016, 52, 8827-8844. [CrossRef]

17. Tobler, D.J.; Minto, J.M.; El Mountassir, G.; Lunn, R.J.; Phoenix, V.R. Microscale analysis of fractured rock sealed with microbially induced $\mathrm{CaCO}_{3}$ precipitation: Influence on hydraulic and mechanical performance. Water Resour. Res. 2018, 54, 8295-8308. [CrossRef]

18. Wu, C.; Chu, J.; Wu, S.; Guo, W. Quantifying the Permeability Reduction of Biogrouted Rock Fracture. Rock Mech. Rock Eng. 2019, 52, 947-954. [CrossRef]

19. Seifan, M.; Berenjian, A. Microbially induced calcium carbonate precipitation: A widespread phenomenon in the biological world. Appl. Microbiol. Biotechnol. 2019, 103, 4693-4708. [CrossRef]

20. Imran, M.A.; Nakashima, K.; Kawasaki, S. Bio-Mediated Soil Improvement Using Plant Derived Enzyme in Addition to Magnesium Ion. Crystals 2021, 11, 516. [CrossRef]

21. Akiyama, M.; Kawasaki, S. Biogeochemical simulation of microbially induced calcite precipitation with Pararhodobacter sp. strain SO1. Acta Geotech. 2019, 14, 685-696. [CrossRef]

22. Matsubara, H.; Yamada, T. Mathematical modelling and simulation of microbial carbonate precipitation: The urea hydrolysis reaction. Acta Geotech. 2020, 15, 29-38. [CrossRef]

23. Nishimura, I.; Matsubara, H. Coupling simulation of microbially induced carbonate precipitation and bacterial growth using reaction-diffusion and homogenisation systems. Acta Geotech. 2021, 16, 1315-1330. [CrossRef]

24. Matsubara, H.; Tomonori, Y. Mathematical and numerical modelling of limestone dissolution. Environ. Geotech. 2019, 40, 1-12. [CrossRef]

25. Obst, M.; Dynes, J.J.; Lawrence, J.R.; Swerhone, G.D.W.; Benzerara, K.; Karunakaran, C.; Kaznatcheeva, K.; Tyliszczake, T.; Hitchcock, A.P. Precipitation of amorphous $\mathrm{CaCO}_{3}$ (aragonite-like) by cyanobacteria: A STXM study of the influence of EPS on the nucleation process. Geochi. Cosmochim. Acta 2009, 73, 4180-4198. [CrossRef]

26. Sakiyama, H.; Matsubara, H. Physical, chemical, and biological investigation of an unconformity between limestone and sandstone in a coastal area: Iriomote Island case study. Catena 2018, 171, 136-144. [CrossRef]

27. Furukawa, H. Quaternary geologic history of the Ryukyu Islands. Bull. Sci. Eng. Div. Univ. Ryukyus 1979, 27, 99-161.

28. Aydin, A.; Basu, A. The Schmidt hammer in rock material characterization. Eng. Geol. 2005, 81, 1-14. [CrossRef]

29. Viles, H.; Goudie, A.; Grab, S.; Lalley, J. The use of the Schmidt Hammer and Equotip for rock hardness assessment in geomorphology and heritage science: A comparative analysis. Earth Surf. Process. Landf. 2011, 36, 320-333. [CrossRef]

30. Falkner, K.K.; Klinkhammer, G.P.; Ungerer, C.A.; Christie, D.M. Inductively coupled plasma mass spectrometry in geochemistry. Annu. Rev. Earth Planet. Sci. 1995, 23, 409-449. [CrossRef]

31. Ogawa, N.; Kohzu, A.; Wada, E.; Koba, K. Abundances of ${ }^{13} \mathrm{C}$ and ${ }^{15} \mathrm{~N}$ in natural ecosystems. Radioisotopes 1997, $46,632-644$. [CrossRef]

32. Søreide, J.E.; Hop, H.; Carroll, M.L.; Falk-Petersen, S.; Hegseth, E.N. Seasonal food web structures and sympagic-pelagic coupling in the European Arctic revealed by stable isotopes and a two-source food web model. Prog. Oceanogr. 2006, 71, 59-87. [CrossRef]

33. Wickman, F.E. Variations in the relative abundance of the carbon isotopes in plants. Geochim. Cosmochim. Acta 1952, 2, 243-254. [CrossRef]

34. Craig, H. The geochemistry of the stable carbon isotopes. Geochim. Cosmochim. Acta 1953, 3, 53-92. [CrossRef]

35. Götze, J.; Hofmann, B.; Machałowski, T.; Tsurkan, M.V.; Jesionowski, T.; Ehrlich, H.; Kleeberg, R.; Ottens, B. Biosignatures in subsurface filamentous fabrics (SFF) from the Deccan Volcanic Province, India. Minerals 2020, 10, 540. [CrossRef]

36. Horai, H.; Arita, M.; Kanaya, S.; Nihei, Y.; Ikeda, T.; Suwa, K.; Ojima, Y.; Tanaka, K.; Tanaka, S.; Aoshima, K.; et al. MassBank: A public repository for sharing mass spectral data for life sciences. J. Mass Spectrom. 2010, 45, 703-714. [CrossRef] [PubMed]

37. Rasche, F.; Scheubert, K.; Hufsky, F.; Zichner, T.; Kai, M.; Svatoš, A.; Böcker, S. Identifying the unknowns by aligning fragmentation Trees. Anal. Chem. 2012, 84, 3417-3426. [CrossRef] [PubMed]

38. Inoue, A. Formation of clay minerals in hydrothermal environments. In Origin and Mineralogy of Clays; Springer: Berlin/Heidelberg, Germany, 1995; pp. 268-329.

39. Ehrlich, H.; Motylenko, M.; Sundareshwar, P.V.; Ereskovsky, A.; Zgłobicka, I.; Noga, T.; Płociński, T.; Tsurkan, M.V.; Wyroba, E.; Suski, S.; et al. Multiphase biomineralization: Enigmatic invasive siliceous diatoms produce crystalline calcite. Adv. Funct. Mater. 2016, 26, 2503-2510. [CrossRef]

40. Demadis, K.D. Biosilica: Structure, function, science, technology, and inspiration. Am. Mineral. J. Earth Planet. Mater. 2018, 103, 1009-1010. [CrossRef]

41. Falasco, E.; Ector, L.; Isaia, M.; Wetzel, C.E.; Hoffmann, L.; Bona, F. Diatom flora in subterranean ecosystems: A review. Int. J. Speleol. 2014, 43, 231-251. [CrossRef]

42. Vitousek, P.M.; Shearer, G. Kohl, D.H. Foliar 15N natural abundance in Hawaiian rainforest: Patterns and possible mechanisms. Oecologia 1989, 78, 383-388. [CrossRef]

43. Takai, N.; Mishima, Y.; Yorozu, A.; Hoshika, A. Carbon sources for demersal fish in the western Seto Inland Sea, Japan, examined by $\delta^{13} \mathrm{C}$ and $\delta^{15} \mathrm{~N}$ analyses. Limnol. Oceanogr. 2002, 47, 730-741. [CrossRef] 
44. Takai, N.; Mishima, Y.; Hoshika, A.; Yoshihara, K. Carbon sources for benthic animal community in Aki Nada speculated on the basis of carbon and nitrogen stable isotope ratios. Bull. Jpn. Soc. Fish. Oceanogr. 2003, 67, 148-162.

45. Ramón Vidal Romaní, J.; Sanjurjo Sánchez, J.; Rodríguez, M.; Fernández Mosquera, D. Speleothem development and biological activity in granite cavities. Geomorphol. Relief Process. Environ. 2010, 16, 337-346. [CrossRef]

46. Hayashi, N.; Kkuniyasu, K.; Inamori, Y.; Sudo, R. Effect of environmental factors on growth characteristics of Rotatoria. Jpn. J. Water Treat. Biol. 1998, 34, 205-213. [CrossRef]

47. Kashima, N.; Irie, T.; Kinoshita, N. Diatom, contributors of coralloid speleothems, from Togawa-Sakaidani-do cave in Miyazaki prefecture, central Kyushu, Japan. Int. J. Speleol. 1987, 16, 95-100. [CrossRef]

48. Zammit, G.; Billi, D.; Shubert, E.; Kastovsky, J.; Albertano, P. The biodiversity of subaerophytic phototrophic biofilms from Maltese hypogea. J. Czech Phycol. Soc. 2011, 11, 187-201. [CrossRef]

49. Pike, A.W.; Hoffmann, D.L.; García-Diez, M.; Pettitt, P.B.; Alcolea, J.; De Balbin, R.; González-Sainz, C.; De las Heras, C.; Lasheras, J.A.; Montes, R.; et al. U-series dating of Paleolithic art in 11 caves in Spain. Science 2012, 336, 1409-1413. [CrossRef]

50. Bourges, F.; Genthon, P.; Genty, D.; Lorblanchet, M.; Mauduit, E.; d'Hulst, D. Conservation of prehistoric caves and stability of their inner climate: Lessons from Chauvet and other French caves. Sci. Total Environ. 2014, 493, 79-91. [CrossRef]

51. Roldán, M.; Hernández-Mariné, M. Exploring the secrets of the three-dimensional architecture of phototrophic biofilms in caves. Int. J. Speleol. 2009, 38, 41-53. [CrossRef]

52. Koga, N.; Nakagoe, Y.; Tanaka, H. Crystallization of amorphous calcium carbonate. Thermochim. Acta 1998, 318, $239-244$. [CrossRef]

53. Bhuvaneswari, S.; Palanisamy, K.; Subramani, K.; Subramanian, V.K. Polymorphic and morphological transformations of CaCO 3 under $\mathrm{CO}_{2}$ atmosphere and under the Influence of EDTA at $60^{\circ} \mathrm{C}$. Int. Lett. Chem. Physics Astron. 2015, 53, 173-179. [CrossRef] 